\title{
Does Service Quality Only Influence Bank Sustainability with the Presence of Employee Behavior and E-Customer Relationship Management?
}

\author{
Mr. Sagar Kumar Behera ${ }^{1}$; Ms. Smitisikha Guru²; Dr. Durga Prasanna \\ Mahapatra $^{3}$, Dr Priyabrata Panda ${ }^{4}$
}

\author{
${ }^{1}$ Research Scholar, Rajendra University, Balangir, sagar.k.behera@gmail.com. \\ ${ }^{2}$ Research Scholar, Gangadhar Meher University, Sambalpur. smitisikha.guru@gmail.com. \\ ${ }^{3}$ Associate Professor, Department of Commerce, Rajendra University, Balangirdpmahapatra03@gmail.com, \\ ${ }^{4}$ Assistant Professor, School of Commerce, Gangadhar Meher University, Sambalpur, \\ pandapriyabrata@rocketmail.com, 7978123683,9090569357.
}

\begin{abstract}
In a dynamic economy, banks are competing with one another to catch more pieces of market share. Especially in-service industry, the sustainability of the firms is highly influenced by customers' satisfaction. In this context, this paper looks into the e-Customer Relationship Management (CRM) as a cutting-edge complete methodology for initiating, retaining and extending customers' relationship for bank sustainability. The main aim of this paper is to dissect the impact of employee behavior and service quality on bank sustainability, mediated by e-customer relationship management. Both direct impact and indirect impact has been analysed. Data are collected through a questionnaire method. A final sample of two hundred bank customers has been retained after checking the missing values and unengaged responses. The research work is confined to Balangir District of Odisha. Structural equation modelling with a mediation variable is applied for hypothesis testing after examining construct validity, reliability, composite reliability and model fit indices. It is found that employee behavior has no direct impact on bank sustainability; however, it has indirect impact with e-customer relationship management as mediation variable. Moreover, the impact of service quality is insignificant on bank sustainability; however, the same mediating variable has resulted to an indirect impact. The finding of this study can help the bankers for policy formulation in regard to Bank's sustainability.
\end{abstract}

Keywords: Sustainability, Customer relationship management, Customer satisfaction, Employee behavior, Service quality.

\section{INTRODUCTION}

The socially conscious market environment and the pro-sustainability business practices have gained popularity in the $21^{\text {st }}$ century. In firms of public interest like banks, financial sustainability plays a crucial role. The sustainability of this service sector industry is highly dependent upon its customer base. Especially in the present scenario, the market is more focused on the customers, their satisfaction and retention rather than the actual buying and selling event. The customers have become the king without a crown in the market. Thus, from a marketing point of view, customer relationship is fundamentally imperative for the organizations to sustain, survive and gain a competitive advantage. Any failure in management of a positive relation with the customers can adversely affect the relationship strength and the firm may lose its customer base (Darzi, 2016).

In today's well-connected world, the internet has provided the customers with greater than ever power. Further, customer satisfaction is a more individualistic phenomenon as the preferences and need of each customer vary from individual to individual (Popovich, 2003). Iriqat and Daqar (2017) have outlined customer satisfaction as a measure to 
evaluate if the product or service bundle supplied by the organization converges or surpasses the expectations of the customer or not. It acts as a parameter to assess the firm's position in the market and a yardstick for improvement.

The satisfaction of a customer can be ensured if the expected and perceived quality of service matches with the actual service delivery (Changet al, 2017). Traditionally, CRM has been adopted as a collaborative approach that includes business processes, technology and laws that promote customers relationship with the organization (Tohidi,2012). Eventually, collaboration of relationship marketing strategies and IT has formed a base for social CRM or the e-CRM that is more promising to create profitable and long-lasting relationship with not just the customers but also with other stakeholders likethe employees of the organization (Stevens, 2008; Chen and Popovich, 2003; Goulding and Abley, 2019). Therefore, it can be said that, adoption of strategies like CRM in general and e-CRM in particular that focuses on maintaining and enhancing the relationship of existing customers with the organization is essentially crucial for banks in India (Roy and Shekhar, 2010). Given the context, the paper aims at evaluating the impact of service quality and behavior of employees on the banks' sustainability by dissecting the mediation role played by e-CRM for strengthening the bank's endurance.

\section{RELEVANCE OF THE STUDY}

The firms need to establish long-term relationship with its stakeholdersthat will not only be benefiacial for the sustainance of the firm but also for value addition to the real economy (David and Laurie,2012).Sustainability has emerged as a global trend now. Many prior studies have emphasied on the role and effect of service quality and behavior of employees on the effciency of the firms. Even, many researchers have studied these aspects as factors within the CRM system.Positive word-of-mouth from a satisfied customer can be a zero-investment advertisement agent (Iriqat and Daqar, 2017). However, in today's contactless-yet-connected world, it is necessary to evaluate the role played by these factors(viz. Service quality and employee behavior) in the light of the e-CRM system that targets all the segments of the customers and evaluates its importance in maintaining sustainability of the banking system. Moreover, Customer service and follow up action has a significant association in determining customer satisfaction (Rodet al., 2008).

\section{REVIEW OF LITERATURE}

\subsection{CRM, e-CRM and Bank Sustainability}

Verhoef (2003) found that attaching commitment, loyalty and emotional values to the programs and providing the customers with economic benefits like scratch cards, cash-backs and other similar promotional offers favourably help in customer retention and market share development.Bompolis(2014) and Lehmkuhlet al,. (2013) acknowledged the natural evolution of the traditional CRM technology and regarded the web powered CRM as social CRM or the CRM 2.0. The author said that the CRM 2.0 can be considered as a new environment that will not only simply interact with the customers but also have a reciprocal conversation with the customers, will accept their value propositions and also learn from them either, directly or indirectly. The effectiveness of marketing strategies can be increased significantly by incorporating CRM in the techniques and processes (Hassanet al., 2015). Effective commitment, satisfaction and CRM performance-based behavior are the basic or the core products that will identify an organization in the competitive world. Many affirmative results have been derived from the prior studies (Mithaset al., 2005; Aralet al., 2006; Dardanet al., 2006; Hendrickset al., 2007; Bhansaliet al., 2008; Liuet al., 2013). The e-CRM is expected to help to avoid losing customers and effectively gain from business opportunities. A technology driven relationship management will help the organization as well as the customers to have a mutual benefit derived out of it and form the basis for a collaborative and stronger relationship than the past (Sivarakset al.,2011). Strenitzerova and Gana (2018) suggested a model to simplify the relationship between customer loyalty and satisfaction and their impact on sustainability. They also opined that inclusion of CRM into business model will effectively help the organisations to attain sustainability.The basic principles underlying eCRM systems that have been described in many literatures are: customer, relationship and management, which converge with the principles of sustainability. e-CRM can therefore be seen as a mediating system that helps the banks in sustainable performance.

\subsection{Employee Behavior and Bank Sustainability}

The environment of an organisation is a totality of various stakeholders that have some inherent 
interest related to the firm. Out of all the stakeholders, the employees are the most crucial as they are the faces that represents the values and beliefs of the organisation itself. They represent the organisation towards the customers and the society. The stability and efficiency of an organisation highly depends on the work-culture and environment provided to the employees (Zhanget al., 2013, Gochhayat et al., 2017). A democratic management system and a participative decision making process promotes a healthy work environment and also stimulates positive in-service behavior of employess (Mizrahi, 2002; Manika, 2013). The employees tend to attach values to their experience within the organisation and reciprocate with a similar typeof behavior. In simple words, a positive perception towards the organisation is reciprocated with high quality social exchages and a negative perception is reciprocated with lower quality exhanges (Dusterhofet al., 2013, Suar et al., 2017). BurmannandZeplin (2004) also gave a very beautiful example of Starbucks where they stated that, Starbucks unlike other firms, spends very little ontraditional advertisements. It rather expects its employees to create a noteworthy experience on the part of the customers. This helps the organization to take advantage of a positive word-of-mouth that helps to strengthen its customer base. Buttet al., (2018) in their paper examined the factors that determined adoption of Islamic banking among customers. Though Islamic banking is mostly preferred due to religious and cultural beliefs but they stated that in case of conventional banking (i.e. non-users of Islamic banking) the customers perceived the value based on a variety of factors like convenience, satisfaction, service quality, etc. including employee behavior. This shows that the behavior of employees is a determining factor from the point of view of firm's performance.

\subsection{Service Quality and Bank Sustainability}

Alike, other industries that focus on quality of products to attain customer satisfaction, it is natural for the service industry to emphasize their service quality so as to gain a competitive advantage in the market (Culiberg and Rojsek, 2010; Ozbekler and Ozturkoglu, 2019; Kant and Jaiswal, 2017). Many prior studies (Pakuráret al., 2019; Cristobal-Fransiet al., 2019; George and Kumar, 2014; Rodet al.,2008) have demonstrated how service quality affects the customer satisfaction.With digitalisation, a significant shift can be observed from the customers who avail the services offline to the customers who would like to avail the services online from the comfort of their home or place of work without wastage of time. This has expanded the services quality dimensions and enrooted even in the digital world. Self-service online banking technology has been of a great help in attainment of the desired result i.e. customer satisfaction (George and Kumar, 2014, Rup et al., 2021). Ozbekler and Ozturkoglu (2019) made a study using factor analysis where they analysed the importance of sustainability-oriented service quality and its positive impact on consumers' perception and on the sustainability of the firm itself.

\section{RESEARCH GAP}

It is evident from the past literatures that constructs like employee bahiviour, service quality and e -customer relationship management has been used as bank performance and efficiency parameters. Stunning efforts are devoted to assess the infuence of this variables on customer satisfaction or trust and loyalty. But bank sustainability as target varible has got little attention. Inaddition to that, CRM has got prime focus than e-CRM which is largely relevant in congruence with the present pandemic situation. Thus a revised model is proposed for bank sustainability which is left in the reviewed literatures.

The proposed model is as follows.

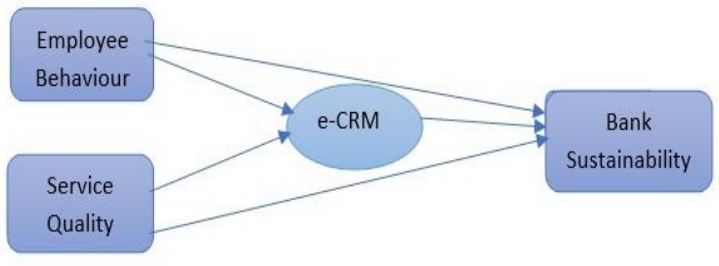

Figure : 1 Proposed Model.

Source : Author's own compilation.

\section{OBJECTIVES}

The research work is conducted with the following objectives.

i. To discect the impact of employee behavior on bank sustainability.

ii. To diagnose the impact of employee behavior on bank sustainability with the mediation effect of ecustomer relationship management.

iii. To measure the impact of service quality on bank sustainability.

iv. To asess the impact of service quality on bank sustainability with the mediation effect of e-customer relationship management. 


\section{HYPOTHESIS}

H01: There is no impact of employee behavior on bank sustainability.

H02: There is no mediation effect of e-customer relationship management when bank sustainability is influenced by employee behavior.

H03: There is no impact of service quality on bank sustainability.

H04 : There is no mediation effect of e-customer relationship management when bank sustainability is influenced by service quality.

\section{DATA AND METHODOLOGY}

\subsection{Sample Size}

There is a difference of opinion in sample size detrrmination for structural equation models. Minimum 200 respondent or sample units are required in any structural equation models (Weston \& Gore, 2006). There may be 10 to 20 participants per estimator (Kline, 1998). But some researchers opined that sample size has little impact on model fit (Jackson 2001, 2003). The present study satisfies the criteria of both Weston \& Gore (2006) and Kline (1998). Questinnaires are distributed to 239 participants. After checking unengaged responses and missing values, 200 sample units are preocessed for the study purpose by using SPSS 20 and AMOS 20 software.

\subsection{Reliability and Validity Estimates}

Table 1: Reliability and Validity Estimates

\begin{tabular}{lcccccc}
\hline \multicolumn{1}{c}{ Constructs } & $\begin{array}{c}\text { Cronbach's } \\
\text { Alpha }\end{array}$ & CR & AVE & $\begin{array}{c}\text { Square root of } \\
\text { AVE }\end{array}$ & MSV & ASV \\
\hline Employee Behavior & 0.79 & 0.68 & 0.50 & 0.71 & 0.47 & 0.45 \\
Service Quality & 0.87 & 0.88 & 0.59 & 0.77 & 0.54 & 0.43 \\
Bank Sustainability & 0.85 & 0.79 & 0.73 & 0.85 & 0.42 & 0.38 \\
e-Customer Relationship & 0.80 & 0.81 & 0.51 & 0.72 & 0.50 & 0.45 \\
Management & & & & & & \\
\hline
\end{tabular}

Source : Author's own finding

Note: CR: Composite Reliability; AVE : Average Variance Exctracted, MSV: Maximum Shared Variance; ASV : Average Shared Variance.

Table 2: Correlation and Square root of AVE

\begin{tabular}{|c|c|c|c|c|}
\hline Constructs & $\begin{array}{l}\text { Employee } \\
\text { Behavior }\end{array}$ & $\begin{array}{l}\text { Service } \\
\text { Quality }\end{array}$ & $\begin{array}{c}\text { Bank } \\
\text { Sustainability }\end{array}$ & $\begin{array}{l}\text { e-Customer } \\
\text { Relationship } \\
\text { Management }\end{array}$ \\
\hline Employee Behavior & 0.71 & & & \\
\hline Service Quality & 0.69 & 0.77 & & \\
\hline Bank Sustainability & 0.65 & 0.56 & 0.85 & \\
\hline $\begin{array}{l}\text { e-Customer Relationship } \\
\text { Management }\end{array}$ & 0.68 & 0 . & 0.64 & 0.72 \\
\hline
\end{tabular}

Source : Author's own finding

Table 3 : Discriminant Validity through HTMT Score

\begin{tabular}{|c|c|c|c|}
\hline & EB & SQ & e-CRM \\
\hline EB & & & \\
\hline SQ & 0.787 & & \\
\hline e-CRM & 0.780 & 0.794 & \\
\hline BS & 0.738 & 0.738 & 0.790 \\
\hline
\end{tabular}

Source :Authors own finding
The table 1 and 2 above reflects the reliability and validity parameters of four constructs. The parameters are as follows.

Reliability

Cronbach's Alpha $>0.70$ (Cronbach,1951 ;Cortina 1993; Taber, 2016)

Composite Reliability $>0.70$ (Bagozzi\& Yi, 1988, Dragan \&Topolsek, 2014)

Convergent Validity 
Average Variance Extracted (AVE) $>0.50$ (Bagozzi\& Yi, 1988)

Discriminant Validity

AVE > MSV >ASV(Fornell\&Larcker, 1981;Dragan \&Topolsek, 2014)

Square root of AVE $>$ All corresponding Correlations.(Fornell\&Larcker, 1981; Dragan \&Topolsek, 2014).

The present study satisfies all the parameters of reliability and validity.
Table 3 substantiates discriminant validity with HTMT score. Henseleret al.,(2015) disapproved the AVE criteria (FornellandLarcker, 1981) of discriminant validity by suggesting HTMT ratio as more robust.This research work trialled HTMT score for measuring discriminant validity. The threshold value should be less than .90 (Henseleret al.,2015) or .80 (Kline, 2011) to assess such validity between two constructs. The table shows that the HTMT ratio between constructs is less than .80 which satisfies both the criteria.

Table 4 : Model Fit Indices

\begin{tabular}{lcc}
\hline \multicolumn{1}{c}{ Model Fit Indices } & Recommended Value & Obtained Value \\
\hline Normed Chi-Square (Hinkin,1995) & $<3$ & 1.67 \\
GFI (Hooperet.al., 2008; Bagozzi\& Yi, 1988) & $>0.90$ & .904 \\
AGFI (Muenjohn\&Armstrong, 2008) & $>0.80$ & .870 \\
CFI (Browne and Cudeck,1992; Byrne, 2016) & $>0.80$ & .958 \\
RMSEA (Bollen,1989; Browne and & $<0.08$ & .058 \\
Cudeck,1992) & & .949 \\
TLI (Browne and Cudeck,1992; Byrne, 2016) & $>0.95$ & \\
\hline
\end{tabular}

Source : Author's own finding.

Note: GFI : Goodness of Fit Index ; AGFI: Adjusted GoodnessofFit Index; CFI: Comparative Fit Index; RMSEA: Root Mean Square Error of Approximation; TLI: Tucker Lewis Index.

The present model satisfies all the parameters mentioned above.

\section{MODEL AND DISCUSSION}

Table 5: Profile of the Respondents

\begin{tabular}{lcc}
\hline Variables & Frequency & $\begin{array}{c}\text { Percentage } \\
(\%)\end{array}$ \\
\hline Male & Gender & \\
Female & 111 & 55.5 \\
Total & 89 & 44.5 \\
& 200 & 100 \\
20-30 & Age (in years) & \\
30-40 & 136 & 68 \\
40-50 & 33 & 16.5 \\
50 and Above & 22 & 11 \\
Total & 9 & 4.5 \\
& 200 & 100 \\
Every Day & Bank Visits & \\
Once in a & 44 & 22 \\
Week & 55 & 27.5 \\
Once in 15 & 33 & 16.5 \\
Days & & \\
\hline
\end{tabular}

\begin{tabular}{lcc}
\hline $\begin{array}{l}\text { Once in a } \\
\text { Month }\end{array}$ & 39 & 19.5 \\
Rarely & 29 & 14.5 \\
Total & 200 & 100 \\
\hline
\end{tabular}

Source : Author's own finding

It is reflected that more male respondents are paerticipated in the survey. The proportion of young customers which is $68 \%$, are much more than other partcipants. It is also observed that the proportion of customers who visit the bank once in a week is more than other customers. It can be infered that the demographic profile of the respondents can support the study purpose.

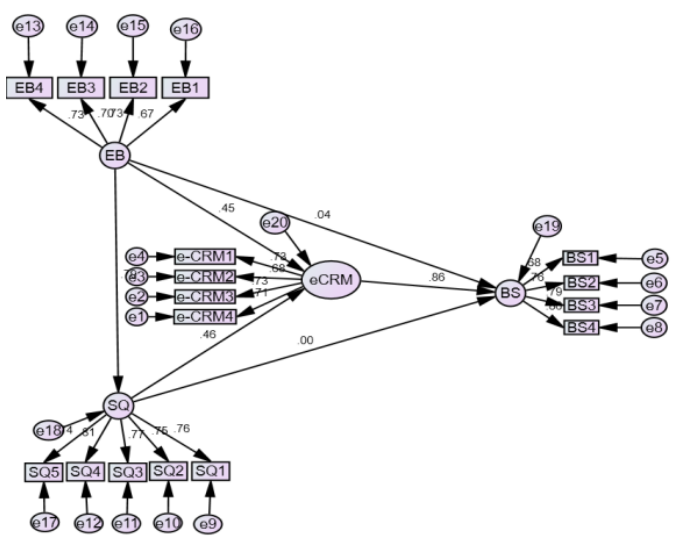

Figure2: Path Analysis of the Model

Source : Authors own finding 
Table6 : Parameter Estimates

\begin{tabular}{|c|c|c|c|c|c|c|c|}
\hline \multicolumn{3}{|c|}{ Influence } & Estimate & S.E. & C.R. & P & Remark \\
\hline SQ & $<---$ & EB & .785 & .097 & 8.158 & $* * *$ & Significant \\
\hline e-CRM & $<---$ & EB & .446 & .130 & 3.483 & $* * *$ & Significant \\
\hline e-CRM & $<---$ & SQ & .463 & .125 & 3.739 & $* * *$ & Significant \\
\hline BS & $<---$ & e-CRM & .858 & .182 & 4.616 & $* * *$ & Significant \\
\hline BS & $<---$ & EB & .041 & .139 & .295 & .768 & Insignificant \\
\hline BS & $<---$ & SQ & .003 & .130 & .020 & .984 & Insignificant \\
\hline
\end{tabular}

Source : Author's own finding.

Note :Estimate: standardized beta co-efficient; SE: standardized error; CR: critical ratio; P: P value; $* * *: \mathrm{P}<0.001)$.

The model results indicate that employee behavior hasdirect influence on service quality and e-customer relationship management. In addition, the impact of service quality on e-customer relationship management is also significant. Perceived service quality is a strongest indicator for customer satisfaction (KhafafaandShafil, 2013, Samanta, 2018).

It is also found that e-customer relationship management has significant impact on bank sustainability. Similar results are witnessed that eCRM significantly influenced customer base. (Sivrakas,2011) and adoption of e-CRM has a positive relationship with satisfaction of customers (Kurian and Joseph, 2018. -However, a few papers also show contradictory results where no significant relation has been found between CRM and performance, profitability and value of firms (Hendrickset al., 2007).

Service quality and employee behavior has no direct influence on bank sustainability. However, it has indirect influence through e-customer relationship management. Thus, the $\mathrm{H} 01$ and $\mathrm{H} 03$ are accepted as $\mathrm{p}$ value is more than .05 for both the cases. But $\mathrm{H} 02$ and $\mathrm{H} 04$ are rejected at 1\% level of significance. It is a case of full mediation as direct effect is insignificant but indirect effect is significant.

Table7 : Sobel Test for the Significance of Mediation

\begin{tabular}{ccc}
\hline DV-MV-IV* & $\begin{array}{c}\text { Sobel } \\
\text { Statistics }\end{array}$ & P Value \\
\hline EB-CRM-BS & 2.80 & 0.005 \\
SQ-CRM-BS & 2.73 & 0.006
\end{tabular}

Source : Author's own finding.

*Dependent Variable-Mediation VariableIndependent Variable.
The mediation effect is robust and confirmed as the Sobel statisticsis significant at $1 \%$ level(Sobel, 1987;Baronet al.,1986). Further, to check common method bias, the standardised regression weights are differentiated before and after implication of a common latent factor. It is found that the differences are less than 0.2. Hence, the model is free from common bias.

\section{POLICY IMPLICATIONS}

The findings of the study ensures that service quality can not be the sole determinant of bank sustainability. Similarly, banks can not bet on employee behavior as an single factor for bank sustainability. But both the variables can have significant influence through e-CRM on bank sustainability. The mediation model expressed that eCRM can influence bank sustaiability. It is also prudent that e-CRM is an important factor in relationship marketing(Chen and Chen, 2004). There is a positive impact of e-CRM on customer satisfaction (Bataineh, 2015). SBI, ICICI bank and Citi bank are leading players among the e-CRM service providers in public, private and foreign banks respectively. Thus, Policy makers should moot ecustomer relationship management as an antigen epitope for bank endurance.

In addition, bank must have to focalise on service quality and employee behavior even these variables have no direct impact. It is evident that there is a strong link between internal customer orientation and internal service quality (Anosike\&Eid, 2010) and service quality leads to customer satisfaction and customer loyalty (MinbandHuu, 2016; Kantet al.,2017). The model also reveals that employee behavior positively affecting service quality. It is prudent that such factor influences trust and loyalty (VisalakshiandKasilingam, 2016). Thus, policy makers and think tanks should cerebrate that bank's continuity can be sustained with employee behavior, service quality and digital customer relationship management. 


\section{CONCLUSION}

Banks, one of the key financial institutions largely depend on its customer base to make balance economic growth and to create an egalitarian utopia. The significsant erosion of customers could have negative influence on its growth and survival. Thus customer relationship management has been gaining momentum. But the ensuing pandemic persuaded digital contact than physical contact. Thus CRM can be transformed to e-CRM. It is rightly inferred by MittalandKumra (2001) that "The banks must adopt e-CRM 'Customer centric' focus approach, as it is believed that products should be devised for the customers and not the other way around". The finding of the presnt study aslo stressedon e-CRM. Only employee bahaviour and service quality can not sustain the bank aliveness. E-customer relationship management strtegically can make the bank to stay alive in competition. Thus,Aralet al., (2006) confirms that ERP and CRM system arevery much effective in stimulating productivity and positive relationship with customers. So, for generating optimum effectiveness out of CRM practices, training the employees through relationship management and technical support, proper and prompt information channel within the internal system of the organization and a highly secured database and interface is a must.

\section{SCOPE FOR FURTHER RESEARCH}

The research study presented in this paper is limited to only Bolangir District of Odisha and has been conducted on a very small sample size of 200 participants only. Thus, a wider sample is needed with a greater number of participants from a larger area of coverage. Moreover, other aspects of e-CRM apart from service quality and employee behavior may also be analysed and enumerated to understand their impact on sustainability of banks.

Appendices 1: Selection of Constructs.

\begin{tabular}{|c|c|c|}
\hline Construct & Codes & Factors \\
\hline \multirow{4}{*}{$\begin{array}{l}\text { Electronic-Customer Relationship } \\
\text { Management } \\
\text { (Sivarakset al.,2011; Chen and Chen, } \\
\text { 2004;Navimipourand Soltani, 2016) }\end{array}$} & e-CRM1 & $\begin{array}{l}\text { There is easy communication } \\
\text { between customer and bank. }\end{array}$ \\
\hline & e-CRM2 & $\begin{array}{l}\text { Bank adheres customer quarries } \\
\text { through phone calls and emails. }\end{array}$ \\
\hline & e-CRM3 & $\begin{array}{l}\text { Bank provides safe and secure e } \\
\text { banking services. }\end{array}$ \\
\hline & e-CRM4 & $\begin{array}{l}\text { ATMs are easily available in } \\
\text { nearby locations. }\end{array}$ \\
\hline \multirow{4}{*}{$\begin{array}{l}\text { Employee Behavior } \\
\text { (Anandetal.,2012;Visalakshiand Kasilingam, } \\
\text { 2016) }\end{array}$} & EB1 & $\begin{array}{l}\text { Customers are dealt with } \\
\text { personal attention. }\end{array}$ \\
\hline & EB2 & $\begin{array}{l}\text { Behavior of the officials are fair } \\
\text { while dealing with complaints. }\end{array}$ \\
\hline & EB3 & $\begin{array}{l}\text { Employees are fairly } \\
\text { knowledgeable to answer the } \\
\text { queries of customers. }\end{array}$ \\
\hline & EB4 & $\begin{array}{l}\text { Employees have a sound } \\
\text { technical knowledge. }\end{array}$ \\
\hline \multirow{5}{*}{$\begin{array}{l}\text { Service Quality } \\
\text { (Alolayyyanet al.,2018; AnosikeandEid, 2010; } \\
\text { MinbandHuu, 2016; Kantet al.,2017;Ai- } \\
\text { HawariandWard, 2006) }\end{array}$} & SQ1 & $\begin{array}{l}\text { Bank renders hassle free } \\
\text { services. }\end{array}$ \\
\hline & SQ2 & $\begin{array}{l}\text { Banking services are speedy in } \\
\text { nature. }\end{array}$ \\
\hline & SQ3 & $\begin{array}{l}\text { Bank provides statement } \\
\text { periodically. }\end{array}$ \\
\hline & SQ4 & $\begin{array}{l}\text { Bank charges less transaction } \\
\text { cost. }\end{array}$ \\
\hline & SQ5 & $\begin{array}{llr}\begin{array}{l}\text { Availability of } \\
\text { friendly } \\
\text { environment. }\end{array} & \begin{array}{r}\text { customer- } \\
\text { transaction }\end{array} \\
\end{array}$ \\
\hline \multirow{2}{*}{$\begin{array}{l}\text { Bank Sustainability } \\
\text { (Igbuduet al., 2018) }\end{array}$} & BS1 & $\begin{array}{l}\text { Bank performs social services } \\
\text { within the locality. }\end{array}$ \\
\hline & $\mathrm{BS} 2$ & $\begin{array}{l}\text { Pro-environmental practices are } \\
\text { adopted. }\end{array}$ \\
\hline
\end{tabular}




\begin{tabular}{|l|l|l|}
\hline \multirow{2}{*}{} & \multirow{2}{*}{$\mathrm{BS} 3$} & $\begin{array}{l}\text { Bank creates awareness among } \\
\text { customers relating to new } \\
\text { products and services. }\end{array}$ \\
\cline { 2 - 3 } & BS4 & $\begin{array}{l}\text { Investments and savings are } \\
\text { fairly profitable. }\end{array}$ \\
\hline
\end{tabular}

\section{REFERENCES}

[1] Al-Hawari, Mohammed, and Tony Ward. "The effect of automated service quality on Australian banks' financial performance and the mediating role of customer satisfaction." Marketing Intelligence \& Planning, vol. 24, no. 2, (2006), pp. 127-147.

[2] Alolayyan, Main Naser, et al. "Banking service quality provided by commercial banks and customer satisfaction. a structural equation modelling approaches." International Journal of Productivity and Quality Management, vol. 24, no. 4, (2018), pp. 543-565, doi:10.1504/ijpqm.2018.093454.

[3] Al-Qeed, MarzouqAyed, et al. "The impact of customer relationship management on achieving service quality of banking sector of Jordan." International Journal of Business and Management, vol. 12, no. 3, (2017), pp. 180, doi:10.5539/ijbm.v12n3p180.

[4] Anand, M., and R. Renganathan. "Influence of Knowledge Management for the Success of Telecom CRM." European Journal of Social Sciences, vol. 36, no. 3, Jan. (2012), pp. 351357.

[5] Ang, Lawrence, and Francis Buttle. "ROI on CRM: A customer-journey approach." IMP Conference, Perth, Australia, vol. 61, no. ECCS (2002), p. 20, http://impgroup.org/uploads/papers/4225.pdf.

[6] Anosike, Uchenna Paschal, and Riyad Eid. "Integrating internal customer orientation, internal service quality, and customer orientation in the banking sector: An empirical study." Service Industries Journal, vol. 31, no. 14, (2011), pp. 2487-505, doi:10.1080/02642069.2010.504822.

[7] Aral, Sinan, et al. "Which came first, it or productivity? the virtuous cycle of investment and use in enterprise systems." ICIS 2006 Proceedings - Twenty Seventh International Conference on Information Systems, (2006), pp. 1819-40, doi:10.2139/ssrn.942291.
[8] Bagozzi, Richard P., and Youjae Yi. "On the evaluation of structural equation models" Journal of the Academy of Marketing Science, vol. 16, no. 1, (1988), pp. 74-94, doi:10.1007/BF02723327.

[9] Baron, Reuben M. Journal of Personality and Social Psychology, vol. 51, no. 6, 1986, pp. 1173-1182.

[10] Bataineh, Abdallah. "The effect of ECRM practices on EWOM on banks' snss: The mediating role of the effect of ECRM practices on EWOM on banks' SNSS: The mediating role of customer satisfaction." International Business Research, June, (2020), doi:10.5539/ibr.v8n5p230

[11] Bhansali, Sumit, and Erik Brynjolfsson. "IT practices and customer satisfaction at 138 large firms." 16th European Conference on Information Systems, ECIS (2008).

[12] Bhat, Suhail Ahmad, and Mushtaq, Ahmad Darzi. "Customer relationship management an approach to competitive advantage in the banking sector by exploring the mediational role of loyalty." International Journal of Bank Marketing, vol. 34, no. 3, (2016), pp. 1-34, doi:10.1108/IJBM-11-2014-0160.

[13] B. K., Rup, J. Gochhayat, S. Samanta, Revisiting Brand Personality Attributes: Mediating Role of Brand Attitude. International Journal of Asian Business and Information Management (IJABIM) 12(2) (2021) 124-136. http://doi.org/10.4018/IJABIM.20210401.oa8

[14] Bollen, Kenneth A. "Structural equations with latent variables." doi:10.1002/9781118619179.

[15] Brockhaus, Sebastian, et al. "Please clap ! how customer service quality perception affects the authenticity of sustainability initiatives." Journal of Marketing Theory and Practice, vol. 25, no. 4, Routledge, (2017), pp. 396-420, doi:10.1080/10696679.2017.1345594.

[16] Brown, Martin, et al. "Deposit withdrawals from distressed banks: Client relationships 
matter." Journal of Financial Stability, vol. 46, Elsevier B.V., (2020), p. 100707.

[17] Browne, Michael W., and Robert Cudeck. "Alternative ways of assessing model fit." Sociological Methods \& Research, vol. 21, no. 2, (1992), pp. 230-58, doi:10.1177/0049124192021002005.

[18] Burmann, Christoph, and Sabrina Zeplin. "Building brand commitment: A behavioral approach to internal brand management." Brand Management, vol. 12, no. 4, (2005), pp. 279300.

[19] Butt, Irfan. "Determinants of low adoption of Islamic banking in Pakistan." Journal of Islamic Marketing, (2018), doi:10.1108/JIMA-01-20170002.

[20] Byrne, Barbara M. Structural Equation Modeling with AMOS: Basic Concepts, Applications, and Programming. Routledge, (2016).

[21] Cambra-Fierro, Jesu's, et al. "The influence of an organization's corporate values on employees personal jesu buying behavior." Journal of Business Ethics, (2008), pp. 157-67.

[22] Camilleri, Mark Anthony. "Valuing stakeholder engagement and sustainability reporting." Corporate Reputation Review, vol. 18, no. 3, Nature Publishing Group, (2006), pp. 210-22.

[23] Chang, Meehyang, et al. "The relationship between the efficiency, service quality and customer satisfaction for state-owned commercial banks in China." Sustainability, (2017), pp. 1-15.

[24] Chen, Injazz J., and Karen Popovich. "Understanding customer relationship management (CRM): People, process and technology." Business Process Management Journal, vol. 9, no. 5, (2003).

[25] Chen, Qimei, and Hong-Mei Chen. "Exploring the success factors of ECRM strategies in practice." Journal of Database Marketing \& Customer Strategy Management, vol. 11, no. 4, (2004), pp. 333-343., doi:10.1057/palgrave.dbm.3240232.

[26] Cortina, Jose, M. "What is coefficient alpha? An examination of theory and applications."Journal of Applied Psychology, 78(1), 98-104. doi:10.1037/0021-9010.78.1.98.
[27] Cristobal-fransi, Eduard, et al. "Exploring service quality among online sharing economy platforms from an online media perspective." Sustainability, (2019).

[28] Cronbach, Lee J. "Coefficient alpha and the internal structure of tests." Psychometrika, vol. 16, no. 3, (1951), pp. 297-334., doi:10.1007/bf02310555.

[29] Culiberg, Barbara. "Identifying service quality dimensions as antecedents to customer satisfaction in retail banking." Economic and Business Review, vol. 12, no. 3, (2010), pp. 151-66.

[30] D. Suar, J. Gochhayat, J. Suar, Influence of Self-esteem on Ethical Behaviors and Corporate Responsibility Values: The Mediating Role of Power-distance, Global Business Review 17(6) (2016) 1401-1411. doi:10.1177/0972150916660405

[31] Dardan, Shana, et al. "The impact of customerrelated IT Investments on customer satisfaction and shareholder returns." Journal of Computer Information Systems, vol. 47, no. 2, (2006), pp. 100-11, doi:10.1080/08874417.2007.11645958.

[32] David, K., S. Laurie. "Strong, straightforward and sustainable banking: Financial capital and impact metrics of values based banking" Global Alliance for Banking on Values, (2012).

[33] Dimitriadis, Sergios, and Eric Stevens. "Integrated customer relationship management for service activities: An internal/external gap model." Managing Service Quality, vol. 18, no. 5, (2008), pp. 496-511, doi: $10.1108 / 09604520810898857$.

[34] Dragan, Dejan and DarjaTopolsek. Introduction to Structural Equation Modeling: Review, Methodology and Practical Applications, The 11th International Conference on Logistics, (2016), 1-27.

[35] Dusterhoff, Carrie, et al. "The effects of performance rating, leader - member exchange, perceived utility, and organizational justice on performance appraisal satisfaction: Applying a moral judgment perspective." Journal of Business Ethics, (2013), doi:10.1007/s10551013-1634-1.

[36] Dwenger, Nadja, et al. "Firms' financial and real responses to credit supply shocks: Evidence from firm-bank relationships in germany." 
Journal of Financial Intermediation, vol. 41, Elsevier Inc., (2020), doi:10.1016/j.jfi.2018.01.003.

[37] Fornell, Claes, and David F. Larcker. "Structural equation models with unobservable variables and measurement error: Algebra and statistics." Journal of Marketing Research, vol. 18, no. 3, (1981), p. 382, doi:10.2307/3150980.

[38] George, Ajimon, and G. S. Gireesh Kumar. "Impact of service quality dimensions in internet banking on customer satisfaction." Decision, (2014), doi:10.1007/s40622-0140028-2.

[39] Ghalenooie, Mehdi Bagheri, and HoseinKhorramiSarvestani. "Evaluating human factors in customer relationship management case study: Private banks of Shiraz city." Procedia Economics and Finance, vol. 36, no. 16, Elsevier B.V., (2016), pp. 363-73, doi:10.1016/s2212-5671(16)30048-x.

[40] Giannakis-Bompolis, Christos, and Christina Boutsouki. "Customer relationship management in the era of social web and social customer: An investigation of customer engagement in the Greek retail banking sector." Procedia - Social and Behavioral Sciences, vol. 148, Elsevier B.V., (2014), pp. 67-78, doi:10.1016/j.sbspro.2014.07.018.

[41] Giovanni, M. Guerci, et al. "The impact of human resource management practices and corporate sustainability on organizational ethical climates: An employee perspective." Journal of Business Ethics, (2013), doi:10.1007/s10551-013-1946-1.

[42] Goulding, Steve, and Richard Abley. Relationship Management in Banking: Principles and Practice. Kogan Page Limited, (2019).

[43] Hassan, Rana Saifullah, et al. "Effect of customer relationship management on customer satisfaction." Procedia Economics and Finance, vol. 23, no. October 2014, Elsevier B.V., (2015), pp. 563-67, doi:10.1016/s22125671(15)00513-4.

[44] Hendricks, Kevin B., et al. "The impact of enterprise systems on corporate performance: A study of ERP, SCM, and CRM system implementations." Journal of Operations
Management, vol. 25, no. 1, (2007), pp. 65-82, doi:10.1016/j.jom.2006.02.002.

[45] Henseler, Jörget.al."A new criterion for assessing discriminant validity in variancebased structural equation modeling." Journal of the Academy of Marketing Science, vol. 43, no. 1, (2014), pp. 115-35, doi:10.1007/s11747-0140403-8

[46] Hinkin, Timothy R. "A review of scale development practices in the study of organizations." Journal of Management, vol. 21, no. 5, (1995), pp. 967-88, doi:10.1177/014920639502100509.

[47] Hooper, Daire, et.al."Structural equation modelling: Guidelines for determining model fit." Electronic Journal of Business Research Methods, vol. 6, no. 1, (2008), pp. 53-60.

[48] Igbudu Nicholas, et.al."Enhancing bank loyalty through sustainable banking practices: The mediating effect of corporate image", Sustanability, vol. 10, no 4050, (2018).

[49] Iriqat, Raed Ali, and Mohannad A. M. Abu Daqar. "The role of customer relationship management on enhancing the customers' satisfaction in the banks in Palestine." Modern Applied Science, vol. 11, no. 12, (2017), p. 84, doi:10.5539/mas.v11n12p84.

[50] Jackson, L., Dennis. "Sample size and number of parameter estimates in maximum likelihood confirmatory factor analysis: A monte carlo investigation." Structural Equation Modeling: A Multidisciplinary Journal, 8:2, 205-223, (2011), DOI: 10.1207/S15328007SEM0802_3.

[51] Jafari,Navimipour, Nima, and ZeynabSoltani. "The impact of cost, technology acceptance and employees' satisfaction on the effectiveness of the electronic customer relationship management systems." Computers in Human Behavior, vol. 55, Elsevier Ltd, (2016), pp. 1052-66, doi:10.1016/j.chb.2015.10.036.

[52] J. Gochhayat, V.N., Giri, D. Suar, Influence of Organizational Culture on Organizational Effectiveness: The Mediating Role of Organizational Communication, Global Business Review 18(3) (2017) 691-702. doi:10.1177/0972150917692185

[53] Joju J, Vasanrtha, S. and Manoj, P. K. "ECRM : A perspective of urban \& rural banks in Kerala." International Journal of Recent 
Advances in Multidisciplinary Research Vol. 02, Issue 09, Pp.0786-0791, September, (2015), vol. 02, no. 09, (2015), pp. 786-91.

[54] Kant, Rishi, et al. "The investigation of service quality dimensions, customer satisfaction and corporate image in Indian public sector banks: An application of structural equation model(SEM)." Vision, vol. 21, no. 1, (2017), pp. 76-85, doi:10.1177/0972262916681256.

[55] Khafafa, Ali Joma, and ZurinaShafii. "Measuring the perceived service quality and customer satisfaction in Islamic bank windows in Libya based on structural equation modelling (SEM)." Afro Eurasian Studies, vol. 2, no. 1\&2, (2013), pp. 56-71.

[56] Kline, Rex B. Principles and Practice of Structural Equation Modeling. Guilford Press, (2011)

[57] Kline, Rex B. Principles and Practice of Structural Equation Modeling. New York, (1998).

[58] Kurian, Abyson, and Riya Joseph. "Impact of electronic customer relationship management on loyalty and satisfaction in private sector banks." Commerce Spectrum, vol. 6, no. 1, (2018), pp. 29-33.

[59] Lehmkuhl, Tobias, and Reinhard Jung. "Towards social CRM - scoping the concept and guiding research." 26th Bled EConference EInnovations: Challenges and Impacts for Individuals, Organizations and Society, Proceedings, (2013), pp. 190-205.

[60] Liu, Alfred Zhu, et al. "How do competitive environments moderate CRM value?" Decision Support Systems, vol. 56, no. 1, (2013), pp. 462-73, doi:10.1016/j.dss.2012.11.003.

[61] Manika, Danae, et al. "The impact of individual attitudinal and organisational variables on workplace environmentally friendly behaviors." Journal of Business Ethics, (2013), doi:10.1007/s10551-013-1978-6.

[62] Minb, Ngo, Vu and Huu, Huan, Nguyen. "The relationship between service quality, customer satisfaction and customer loyalty: an investigation in Vietnamese retail banking sector." Journal of Competitiveness, vol. 8, no 2,(2016), pp. 103-116.
[63] Mithas, Sunil, et al. "Why do customer relationship management applications affect customer satisfaction?" Journal of Marketing, vol. 69, no. 4, (2005), pp. 201-09.

[64] Mittal, K., R., \& Rajeev Kumra. "E-CRM in Indian banks an overview." Delhi business Review, vol. 2, no. 1, (2001).

[65] Mizrahi, Shlomo. "Workers' Participation in decision- making processes and firm stability." British Journal of Industrial Relations, no. December, (2002), pp. 689-707.

[66] Muenjohn, Nuttawuth, and Anona Armstrong. "Evaluating the structural validity of the multifactor leadership questionnaire (MLQ), capturing the leadership factors of transformational-transactional leadership." Contemporary Management Research, vol. 4, no. 1, (2008), doi:10.7903/cmr.704.

[67] Naser, A., Al-Hawary, S., Mohammad, A., AlNady, B. "Banking service quality provided by commercial banks and customer satisfaction. A structural equation modelling approaches." International Journal of Productivity and Quality Management, vol. 24, no. 4, (2018), pp. 543-65.

[68] Ngo, Minh Vu, and Huu Huan Nguyen. "The relationship between service quality, customer satisfaction and customer loyalty: An investigation in Vietnamese retail banking sector." Journal of Competitiveness, vol. 8, no. 2, (2016), pp. 103-16, doi:10.7441/joc.2016.02.08.

[69] Nwagwu, Dr Ijeoma. "Driving sustainable banking in Nigeria through responsible management education: The case of Lagos business school." International Journal of Management Education, vol. 18, no. 1, Elsevier, (2020), p. 100332, doi:10.1016/j.ijme.2019.100332.

[70] Ozbekler, Turkan Muge. "Analysing the importance of sustainability-oriented service quality in competition environment." Business Strategy and the Environment, no. December 2019, (2020), pp. 1-13, doi:10.1002/bse.2449.

[71] Pakurár, Miklós, et al. "The service quality dimensions that affect customer satisfaction in the Jordanian banking sector." Sustainability, vol. 11, no. 4, (2019), p. 1113. 
[72] Rezapouraghdam, Hamed, et al. "Workplace spirituality and organization sustainability: A theoretical perspective on hospitality employees' sustainable behavior." Environment, Development and Sustainability, Springer Netherlands, (2018), doi:10.1007/s10668-0180120-4.

[73] Rigtering, J. P. C., and U. Weitzel. "Work context and employee behavior as antecedents for intrapreneurship." International Entrepreneurship and Management Journal, (2013).

[74] Rishi Kant, R., Jaiswal, D. "The impact of perceived service quality dimensions on customer satisfaction: An empirical study on public sector banks in India." International Journal of Bank Marketing, vol. 35, no. 3, (2017), doi:10.1108/IJBM-04-2016-0051.

[75] Rod, Michel, and Nicholas J. Ashill. "An examination of the relationship between service quality dimensions, overall internet banking service quality and customer satisfaction a New Zealand study." Marketing Intelligence \& Planning, vol. Vol. 27 No, (2008), pp. 103-26.

[76] Roeck, Kenneth De, and Nathalie Delobbe. "Do environmental CSR initiatives serve organizations' legitimacy in the oil industry? exploring employees' reactions through organizational identification theory." Journal of Business Ethics, (2012), doi:10.1007/s10551012-1489-x.

[77] Roy, Sanjit Kumar, et al. "Measuring effectiveness of customer relationship management in Indian retail banks." International Journal of Bank Marketing, vol. 30, no. 4, (2012), pp. 246-66.

[78] S. Samanta, Social Entrepreneurship Promoting Inclusivity, Empowerment and Participative Governance-A Bibliographic Insight, The Indian Journal of Commerce 71 (03 \& 04) (2018) 34-48.

[79] Sin, Leo Y. M., et al. "CRM: Conceptualization and scale development." European Journal of Marketing, vol. 39, no. 11-12, (2005), pp. 1264-90, doi:10.1108/03090560510623253.

[80] Sivaraks, Phavaphan, et al. "Effects of E-CRM on customer-bank relationship quality and outcomes: The case of Thailand." Journal of High Technology Management Research, vol.
22, no. 2, Elsevier Inc., (2011), pp. 141-57, doi:10.1016/j.hitech.2011.09.006.

[81] Sobel, E. "Direct and indirect effects in linear structural equation models." Sociological Methods \& Research, vol. 16, no. 1, (1987), pp. 155-76.

[82] Soltani, Zeynab, et al. "The impact of the customer relationship management on the organization performance." Journal of High Technology Management Research, vol. 29, no. 2, (2018), pp. 237-46, doi:10.1016/j.hitech.2018.10.001.

[83] Strenitzerov, Mariana. "Customer satisfaction and loyalty as a part of customer-based corporate sustainability in the sector of mobile communications services." Sustainability, (2018).

[84] Taber, Keith S. "The use of Cronbach's alpha when developing and reporting research instruments in science education." Research in Science Education, vol. 48, no. 6, Research in Science Education, (2018), pp. 1273-96, doi:10.1007/s11165-016-9602-2.

[85] Tohidi, Hamid, and Mohammad Mehdi Jabbari. "CRM as a marketing attitude based on customer's information." Procedia Technology, vol. 1, (2012), pp. 565-69.

[86] Vaish, Aditya, et al. "Customer relationship management (CRM) towards service orientation in hospitals: A review." Apollo Medicine, vol. 13, no. 4, Indraprastha Medical Corporation Ltd., (2016), pp. 224-28, doi:10.1016/j.apme.2016.11.002

[87] Verhoef, Peter C. "understanding the effect of efforts on customer retention." Journal of Marketing, vol. 67, no.October,(2003), pp. 3045, doi:10.1016/j.intmar.2011.02.002.

[88] Visalakshi, S, and R Kasilingam. "Learning and growth perspective of the balanced scorecard in commercial banks in India." Journal of Psychological Researches, vol. 60, no. 1, Jan. (2017), pp. 28-37.

[89] Weston, Rebecca, and Paul A. Gore. "A brief guide to structural equation modeling." The Counseling Psychologist, vol. 34, no. 5, (2006), pp. 719-51, doi:10.1177/0011000006286345.

[90] Yay, Meral. "The mediation analysis with the Sobel test and the percentile bootstrap." 
International Journal of Management and Applied Science, vol. 3, no. 2, (2017), pp. 12931.
[91] Zhang, Mingqiong, et al. "High-performance work systems, corporate social performance and employee outcomes: Exploring the missing links." Journal of Business Ethics, (2014), pp. 423-35, doi:10.1007/s10551-013-1672-8. 